\title{
Ligheder og forskelle i nyere teorier om praktikernes erkendelsgrundlag
}

\author{
Karin Anna Petersen \\ Professor i sykepleievitenskap, Universitetet i Bergen
}

\begin{abstract}
Similarities and differences in newer theories on the basis of cognition of practicians

The article is built around different theoretical positions on practical cognition. The empirical starting point is clinical nursing and the corresponding theoretical education/formal training, as this is materialized in a modern society where reflexivity is a manifest requirement. However, the epistemological question concerns all practicians: What parts of him or herself does the practitian use when practicing? And where does it come from?
\end{abstract}

Keywords: Practical cognition, clinical nursing, theoretical education, reflexivity

\section{Sammendrag}

Artiklen er opbygget omkring forskellige teoretiske positioner om den praktiske erkendelse. Det empiriske afsæt er den kliniske sygepleje og den modsvarende teoretiske uddannelse, sådan som denne konkret materialiserer sig i et moderne samfund, hvor refleksivitet er et manifest krav. Det erkendelsesteoretiske spørgsmål vedrører imidlertid alle praktikere: Hvad er det praktikeren bruger af sig selv, når han udøver sin praksis? Og hvor kommer det fra?

Nøgleord: Praktisk erkendelse, klinisk sygepleje, teoretisk uddannelse, refleksivitet

Teksten er tidligere publiceret i Petersen, K. A. (Red.)(1995a, s. 81-100).

Publisert: 25.08 .2020

Praxeologi - Et kritisk refleksivt blikk på sosiale praktikker @2020 Karin Anne Petersen

DOI: http://dx.doi.org/10.15845/praxeologi.v2i0.3123 


\section{Fra øvelse, imitation og erfaring til abstrakte principper, regler og kodificeringer}

Omkring 1860'erne blev sygepleje primært lært i praktikken af praktikere ved sygesengen med opgaver som at gå til hånde, iagttage de syges tilstand, give beretning herom, udvise lydighed og ærbødighed og med elevinstrukser, der især drejede sig om pligter og anvisninger for, hvordan disse pligter skulle indfries. Forudsætninger var ingen eller en god vandelsattest.

Siden 1990'erne har sygeplejerskeuddannelsen i hvert fald uformelt krævet studentereksamen, og uddannelsen er opbygget $i$ en mere eller mindre formel struktur, hvor man efter en praktisk/teoretisk grunduddannelse på knap 4 år i undervisningsministeriets regi kan få dansk autorisation og kalde sig bachelor $\mathrm{i}$ udlandet. Efter yderligere $2 \frac{1}{2}$ år i sundhedsministeriets regi kan man blive kandidat i sygepleje, candidatus curationis. Efter endnu 3 års studier kan man blive Ph.D. $i$ sygeplejevidenskab i forbindelse med en samarbejdsaftale indgået med Danmarks Sygeplejerskehøjskole ved Aarhus Universitet, Medicinsk fakultet ved Aarhus Universitet og Statens Sundhedsvidenskabelige Forskningsråd (Petersen, 1993, s. 10-76 og Jørgensen, 1994, s. 9-13).

Det interessante er, at man ved simple observationsstudier af sygeplejerskernes virksomhed i den kliniske sygeplejepraksis kan iagttage, at de opgaver, som varetages af en sygeplejerske i en vis forstand, stort set er uændrede gennem mere end 100 år. Det vedrører fortsat at gå til hånde, iagttage de syges tilstand, give beretning herom, at udvise lydighed og ærbødighed, og elevinstrukserne drejer sig fortsat om pligter og anvisninger til opfyldelsen heraf (Petersen, 1989 /90, s. 24-39, 49-76 og 1993, s. 205-240).

Legitimiteten i sygeplejen viser sig at være forbundet med opkomsten af klinikken, som Foucault benævner det, og den kliniske medicins udvikling (Foucault, 1973 og 1977, s. 157). Alligevel har man for at kunne varetage disse opgaver fundet det nødvendigt, at sygeplejersken gennemfører en uddannelse, der i sin opbygning over tid indeholder mere og mere teori (fra ca. 10\% af uddannelsestiden i 1939 til 55\% i 1990), opsplittet på en mængde videnskabeligt baserede deldiscipliner og et enkelt samlende fag, der benævnes sygepleje, og som er praktisk funderet uden umiddelbar videnskabelig legitimitet, men som man dog aktuelt arbejder på skal etableres som videnskabsfag.

Det betyder, at sygeplejerskeuddannelsen i dag varer kvantitativt fra knap 4 år til $91 / 2$ år, forudgået af 12 års skolegang.

Det vil sige, at vi har en problemstilling, som går på, at praktiske færdigheder, som tidligere erhvervedes gennem $\emptyset$ velse, imitation og erfaring med og inden for det konkrete virksomhedsfelt, $\mathrm{i}$ dag først og fremmest forventes lært gennem en skolemæssig uddannelsessammenhæng som abstrakte principper, regler og kodificeringer om praktikken, som så siden forventes omsat til praktikerfeltets praktikker (Larsen, 1991).

\section{Fra kognitiv til kontekstuel orientering}

Det tjener til specifik belysning af sygepleje som aktuel "case", at diskussionen om praktikerens erhvervskundskab under termen tavs kundskab i særlig grad inden for dette felt, og ikke uden grund, har været diskuteret og studeret op igennem 1980'erne, mens den tilsvarende pædagogiske debat mere har haft fokus på kognitiv forskning, hvor man har diskuteret kundskabsdannelse som hierarkiske trin på vej mod den endegyldige og "rigtige" forståelse. Det vil sige, at man går fra én dekontekstualiseret forståelse til den næste. Først inden for de senere år er diskussionen om tavs kundskab, også benævnt "Teachers' thinking", tiltaget inden for pædagogisk forskning om lærerkundskab, hvor fokus er på kontekstualisering som et forkropsliggjort kundskabsbegreb i 
forsøget på at beskrive det uartikulerede i lærervirke. ${ }^{1}$ Det vil sige, at man har været optaget af ikke bare generelle og abstrakte læreprocesteorier, men også af hvilken erkendelse som styrer lærerens pædagogiske praksis.

Eller vi kan med Ingrid Carlgren sige, at store dele af forskningen hidtil har ladet sig nøje med at studere kundskabens kognitive del og derved forholdt sig til kundskab som til toppen af et isbjerg. Men det gælder for kundskab som for isbjerge, at der findes flere lag under det, som umiddelbart fremstår, og som derfor må medreflekteres, hvis man vil forstå alt det, som muliggør den kognitive del af kundskab (Carlgren, 1990, p. 97).

Eller vi kan spørge: Skal man for at opnå et videnskabeligt niveau bortse fra konteksten, eller findes der en videnskabelig viden, som fastholder konteksten? At der findes en praktisk viden, der fastholder konteksten, det ved vi.

\section{Sekulariseringen muliggjorde andre forståelser end den religiøse/teologiske}

Det, vi altså kan slå fast, er, at vi har at gøre med en fælles problemstilling for pædagogik og sygepleje, som i virkeligheden gælder for hele feltet af mellemuddannelser set som en praktikererhvervenes kundskabsproblematik. Men samtidig er denne problemstilling om den praktiske erkendelse symptomatisk for det Moderne, forstået som tiden efter reformationen ${ }^{2}$ og oplysningstiden ${ }^{3}$, hvor kognitiv rationalitet, moralsk autonomi og social og politisk selvbestemmelse står som centrale begreber for sekulariseringen op imod tidligere tiders autoritative teologiske åbenbarelsesbegreb, moralsk heteronomi og feudalsamfund.

Dermed bliver problemstillingen flyttet fra at være en specifik analyse af sygeplejefaget og den modsvarende uddannelse til at være en eksemplarisk casebeskrivelse af det moderne menneskes filosofiske og samfundsmæssige diskussion af det substantielle spørgsmål: Mennesket som rationelt væsen?

Sekulariseringen muliggjorde opkomsten af andre forståelser end den religiøse/teologiske. Spørgsmålet om, hvordan man som menneske bliver klog på denne verden, fandt ikke længere sine svar i de religiøse skrifter. Erstatningen for teologien blev filosofien, der senere som praktisk filosofi afløses af enkeltvidenskaberne som psykologi, sociologi, pædagogik mv., der alle legitimerer sig gennem retten til at omhandle et vist tema fri af teologien. Det blev med Auguste Comte videnskabens opgave at overtage religionen. Sociologien og psykologien bliver det nye præsteskab, og det, der tidligere har været en religiøs diskurs, gøres nu til genstand for en videnskabelig diskurs. Det drejer sig ikke længere om åbenbarelse, autoritetstro, spekulation, følelser og ideologi, men om det, der er givet, som er til stede (Durkheim, 1972). Det gælder om at positivere; alt kan gøres synligt og måleligt. Den menneskelige erfaring bliver det sekulariserede åbenbarelsesbegreb, og den frie diskussion autoriteten og videnskaben måden, hvorpå forskeren "graver" svarene frem, beskrivelsen af hvorfor verden ser ud, som den gør. Videnskaben sætter altså mennesket op imod tidligere forståelser af sig selv, videnskaben krænker det foregående, videnskaben er polemisk. Kundskab som begreb bliver relativeret og relationelt bestemt. Alt står nu til diskussion.

Problemet er imidlertid, at "den frie diskussion" ikke er så fri endda (Erslev Andersen, Schanz \& Stounbjerg, 1983). Det viser sig nemlig, at den kundskab, der danner basis for diskussionen, er

\footnotetext{
${ }^{1}$ Et godt eksempel på den parallelt løbende diskussion om lærertænkning "Teachers Thinking" som erkendelsesgrundlag for pædagogisk praksis, er F. Elbaz' klassiske afhandling Teachers Thinking. A study of Practical Knowledge fra 1983.

21517 Luthers teser om aflad.

31789 Den franske revolution.
} 
indlejret i kontekstuelle sammenhænge, hvor et socialt hierarki gør sig gældende. Her bliver diskussionen om ligheder og forskelle i nyere teorier om praktikernes erkendelsesgrundlag væsentlig, idet kundskab som entydig kognitiv størrelse ikke længere eksisterer. Det handler altså ikke kun om kundskab, men også om sociale hierarkier.

\section{Doxa og épistème}

I anglosaksisk tradition forstås kundskab som alt det, der artikuleres gennem sproget, mens færdigheder udtrykkes på anden måde og frem for alt "ikke-tavst", men synligt gennem handling. Færdigheder er en kompetance, som fordrer en vis viden, men at kalde den viden for tavs til forskel fra en artikuleret og videnskabelig viden er at argumentere imod noget på modargumentets præmisser, siger Elzinga, således forstået, at praktikeren for at legitimere sin praksis op imod videnskaben må gøre brug af den videnskabelige verdens logikker og sprog fremfor at tale om sagen kontekstuelt, hvilket fordrer magttermer (Eizinga, 1989, s. 125-145 og 1990, s. 115-120).

Elzinga foreslår i stedet Aristoteles distinktion mellem doxa og épistème, hvor doxa vedrører det praktiske, dvs. den erfaringsbundne moralske stillingtagen, mens épistème er det systematiserede og artikulerede (Aristoteles, 1936 og Elzinga, 1990, s. 115). Det vil sige, at vi har med to former for viden at gøre, som har hver sin "egenlogik", og hvor det ikke er muligt at stille samme krav om artikulerbarhed. Elzinga bruger et stærkt eksempel med bøddelen, der har en tavs kundskab om, hvordan han skal slå knude på rebet om ofrets hals. Den dag, hvor den elektriske stol indføres, påberåber bøddelen sin "tavse kundskab" for at undgå dødsteknologien inden for sit erhvervs område. Er det progressivt? spørger Elzinga, og svarer selv nej. En sådan diskussion vedrører et fors $\varnothing \mathrm{g}$ på at hævde sig i en diskussion eller strategi, hvor det gælder om ikke at blive opslugt af moderne teknologi eller af dem, der vil professionalisere et fag (Elzinga, 1990, p. 116). Undertiden kan tale om tavs kundskab med det nævnte eksempel in mente ligefrem være reaktionær tale. Progressiviteten i eksemplet vedrører helt andre forhold, som er forbundet med det kontekstuelle, nemlig moralske, etiske og politiske spørgsmål om dødsstraf overhovedet.

\section{Tavs kundskab - en retorisk term}

Elzinga viser med eksemplet, at diskussionen om tavs kundskab er en retorisk term, en faggruppes forsvarsstrategi over for dem, der gennem magtudøvelse vil indsnævre erhvervsgruppens handlerum.

Hele diskussionen om tavs kundskab skaber forvirring, fordi den gør noget, som ikke er kundskab, til kundskab; eller anderledes sagt: Kundskaben defineres negativt som det, det ikke er, det usagte, fremfor en positiv formulering. Aant Elzinga foreslår i stedet termen: fortroligheds- eller færdighedskundskab.

Elzinga nævner Ingela Josefsons studier af sygeplejersker i England, der i en situation, hvor nye ekspertsystemer skal indføres, polariseres $i$ henholdvis en forherligelse af teknokrati eller romantik (Josefson, 1991):

1. En gruppe, som $\varnothing$ nskede st $\varnothing$ rre administrative og ledende beføjelser og var for indførelsen af ekspertsystemerne.

2. En gruppe, som ønskede at fastholde patientkontakten og omsorgsaspektet og opfattede de nye ekspertsystemer som distancerende til sygeplejearbejdet.

Det vil sige, at termen tavs kundskab bl.a. fungerer som en kategorisering af en social kamp, der blandt andet vedrører angsten for dehumanisering og/eller professionalisering. 
Inden for sygeplejefeltet har denne kamp blandt andet ytret sig gennem forsøget på at definerere medicin som forskellig fra sygepleje gennem en videnskabsteoretisk kamp mellem positionerne, der ikke uproblematisk benævnes naturvidenskab eller positivisme over for fænomenologi, idet sygeplejen forsvarer et videnskabsideal, der medtænker den subjektive dimension til forskel fra medicinens rent objektiverende naturvidenskab (Elzinga, 1990, p. 116-117). Det vil sige, at der skabes en retorisk kamp mellem positivisme på den ene side og hermeneutik på den anden side, der snarere end at udforske, hvad sygeplejersken går og laver, hvilke sammenhænge arbejdet er indlejret i og udvikle teorier herom, er optaget af at forsvare og afgrænse et initialt forskningsfelt, som i virkeligheden kommer til at handle om noget helt andet, nemlig en social kamp mellem to faggrupper, som ville finde en langt mere adækvat form ved at blive beskrevet i magttermer (Elzinga, 1989). ${ }^{4}$

Men samtidig spejler denne retoriske videnskabsteoretiske diskussion en identifikationsproblematik, som projiceres over i videnskabsteoretiske termer, men som også vedrører en intern kamp i sygeplejerskegruppen selv, mellem dem, som vil akademiseres og satser på at tilhøre det akademiske miljø, og dem, som udøver praktikken og snarere er optaget af en faglig kamp (Lindgren, 1992 og Heyman, 1995). For praktikeren kommer den tavse kundskab til at vedrøre legitimiteten og dokumentationen af et afgrænset kundskabmonopol: sygeplejeforskerne i kampen mod medicinen og sygeplejepraktikeren i fors $\varnothing$ get på at synliggøre sin kompetance.

I virkeligheden drejer spørgsmålet sig om sociale relationer, dominans og underordning, magt og magtkrav, siger Elzinga og peger på Foucault som et bedre udgangspunkt for diskussionen mellem faggrupper, idet hvem der bestemmer over hvem samtidig afklarer, hvem der definerer situationen, og hvordan kundskab udmønter sig i en given sammenhæng (Foucault, 1977).

Elzingas argumentation har indtil nu været sprogfilosofisk i talen om tavs kundskab, som han i den nævnte forståelse foretrækker at kalde for skjult kundskab.

\section{Traditionens autonomi eller kundskabens forkropsliggørelse}

Polanyi derimod taler om tavs kundskab, "tacit knowledge" som en kundskab der er vanskelig at sætte ord på, men som kan synliggøres. Polanyi udviklede sit kundskabsbegreb i en forskningspolitisk diskussion af, hvorvidt videnskab skulle styres eksternt gennem blandt andre politiske beslutningstagere, som ikke direkte var involveret i forskning selv (Polanyi, 1967 og Elzinga, 1990, p. 118). Polanyis argumentation var, at også i det teoretiske videnskabelige arbejde findes der en viden som er tavs og som ikke kan bedømmes rationelt eller logisk. Polanyi bliver i dag talerør for de praktikerfag der forsøger at legitimere og fastholde et kompetancemonopol (Göranzon, 1990). Polanyi er således fortaler for en elitær og autoritær kundskabsforståelse, som vanskeliggør kollegial kritik, samtidig med at han har fat i en væsentlig problemstilling ved at påpege den skjulte dimension i kundskabsudviklingen.

Det er samme problematik som Thomas Kuhn tager fat på i diskussionen af normalvidenskab, men forskellen mellem Polanyi og Kuhn er i følge Elzinga, at hvor Polanyi fastholder traditionen, viser Kuhn at normalvidenskaben med tiden selv opviser et sæt af anomalier som efterhånden fører til et paradigmeskift, en videnskabelig revolution (Kuhn, 1973 og Elzinga, 1990, s. 118).

Men hele diskussionen vedrører også genindførelse af kundskabens forkropsliggørelse. Med fastholdelse af traditionens autonomi, som Polanyi gør det, bliver kundskaben mystificeret til at være noget, der befinder sig uden for kroppene og uden for institutionerne, samtidig med at den bliver

\footnotetext{
${ }^{4}$ Som eksempler på studier, der fors $\emptyset$ ger at indkredse hvad en sygeplejerske faktisk går og laver, jf. A.M. Jørgensen (1993) og E.B. Jørgensen (1993), s. 83-96.
} 
elitær og udelukker en demokratisk rationel eftergranskning, hvis den påberåber sig det usigelige. Elzinga vil fastslå, at f.eks. naturvidenskab ikke er positivistisk i sig selv, med mindre den bæres af en positivistisk filosofi. Videnskaben skal altså bedømmes på, om den udsætter sig for kritik.

En anden positivismekritik er forholdet mellem adskillelsen af kundskab i henholdsvis en mentalog en handlingskundskab, eller de sociale epistemologer der reducerer kundskab til sociale sammenhænge, hvor resultatet i sin yderste konsekvens bliver relativistisk, hvor magtkamp kommer til at afgøre, hvad der er sandt, og hvad der er falskt.

Men en vigtig side i Polanyis diskussion er, at der selv i videnskaben findes sider som ikke kan ekspliciteres og artikuleres sprogligt. Det betyder, at også det videnskabelige samfund er en kulturform der foruden de erkendelsesteoretiske, de epistemologiske kriterier, omhandler, hvad Elzinga benævner etos og kontrolinstanser, som det ikke går at se bort fra. Her er Elzinga på linie med Bourdieu, der bruger udtrykket, at videnskab er en social erobring ligesom sygesikringen.

Det betyder, at hvis man kun forstår videnskab som et kundskabsanliggende, hvor det gælder om at sprogliggøre en kunnen, så kan man naturligvis tale om videnskabeligg ørelse af forskellige håndværksmæssige fag. Men forstår man, at også videnskaben er en flerdimensionel kultur, da bliver talen om erhvervspraktikkernes videnskabeliggørelse absurd og selvgendrivende. Praksis ville oph $\varnothing$ re med at eksistere som selvstændig med egne normer, etos og kontrolinstanser, siger Elzinga.

Taler vi kun om det epistemologiske, da kan man skelne mellem kundskab og tavs kundskab, hvor den tavse kundskab vedrører doxa, det vil sige moral og praktisk erfaring, over for épistème, der vedrører den artikulerede kundskab.

\section{Ureflekteret intuition som virtuos kompetence}

Det er miljøet omkring forskningen inden for Computer Science og Artificial Intelligence debatten, som i de senere år har polariseret forholdet mellem rationalitet og intuition. Den traditionelle kognitionspsykologiske tænkning opfatter intuition, som barnets infantile tænkning, der siden erstattes af mere formaliseret regeltænkning.

Brødrene Hubert og Stuart Dreyfus har i denne sammenhæng som henholdsvis filosof og computerekspert gennem deres studier af læring hos blandt andre professionelle piloter og skakspillere vendt hele denne tradition på hovedet ved at antage, at man først lærer regler og principper, det vil sige teoretisk viden, og opfatter fragmentariske dele af en praktisk situation, en kundskab som så siden bundfældes hos eksperten, der ser og opfatter situationen i helheder og handler pr. intuition eller refleks (Dreyfus \& Dreyfus, 1986). Dreyfusbrødrene har til illustration af deres læreproces opbygget en femtrinsmodel for læring, der går fra novice til ekspertniveau: Novicen, der handler regelorienteret, langsomt og symbolsk. Begynderen, der kan reglerne og begynder at kategorisere disse. Den kompetente, der vælger strategier. Den kyndige, der ikke behøver at abstrahere sig ud af situationen. Eksperten, der opfatter $\varnothing$ jeblikkelig og handler per intuition.

Dreyfus'erne mener, at indlæring i princippet kræver, at man gennemgår femtrinsmodellens stadier, uanset om man indlærer en intellektuel færdighed eller en kropslig færdighed. Begge forhold, det vil sige såvel intellektet som kroppen, er væsentlige. Begrebet færdighed overskrider såvel krop som intellekt.

Kvindeforskeren Kirsten Grønbæk Hansen kritiserer Dreyfusbrødrene for ikke at være radikale nok i deres indlæringstænkning, idet de bevarer en hierarkisering fra et lavere regelsystem til et højere niveau, intuition, derved adskiller de indlæringen tidsligt og gør intuition til et rent ekspertiseniveau. Hansen mener Dreyfus'ernes intuitionsbegreb i princippet kan samstilles med ren rutine, og påpeger, at intuition ikke er forbeholdt eksperten og derfor ikke kan hierarkisk placeres (Hansen, 1988). 
Intuition burde i stedet billedligt beskrives som en ring eller en sky, diffus og uafgrænset. Samtidig fastholder Hansen, at Dreyfus'erne, når de fremstiller den intuitive erkendelse som nøgtern, uproblematisk og overlegen, vanskeliggør og tilsidesætter kvindelige forskeres indsigter.

\section{Forskning som legitimationsprojekt}

En væsentlig side i diskussionen af praktikerens erkendelsesgrundlag er forestillingen om, at der til en kvalificeret praksis knytter sig en indhentet videnskabelig viden, men viden $\mathrm{i}$ en ganske bestemt mening. Videnskaben forventes etableret inden for den praktiske virkeligheds problemstillinger, idet praktikerens forventning er, at videnskaben skal hjælpe praktikeren og praktikken over dens problemstillinger. Praksisfeltets legitimering gennem $\emptyset$ gede teoretiske krav er således foranlediget af spørgsmål om oplevede mangler i praktikken, hvor forestillingen er, at forskeren ved bedre og derfor spørges om råd. Forskerens projekt, som hos Benner bliver følgelig et legitimationsprojekt af, at praktikken er god nok, men med visse tiltag kan den yderligere kvalificeres og bedre argumenteres over for samfundsmæssige instanser (Benner, 1984).

Problemet med en sådan legitimerende praksisforskning er imidlertid, at den nemt kommer til at fremhæve praktikerfeltets egeninteresser og følgelig fremstår som utroværdig og i værste fald også kommer til at fungere som en kontrolinstans over for dem, som ud $\varnothing$ ver den konkrete virksomhed $i$ praktikken (Petersen, 1995b).

En sådan professionsrettet kundskabsudvikling i praktikken ligger i direkte forlængelse af praktikerens praktiske viden og kunnen og kommer ved ensidig fokusering herpå til at mangle den teoretiske bevidsthed og problematisering, som foranlediger andre forskningstraditioner til at kunne stille spørgsmål som: Hvordan kan det være, at praktikken ser ud som den gør? Fremfor kun at spørge om: Hvordan kan vi lave praktikken bedre?

Det vil sige, det at gå fra professionsviden og videnskabelige metodikker, som alene har til hensigt at videnskabeliggøre professionsviden på et nyt niveau, der skulle forbedre praktikken, bliver i virkeligheden til, at man forholder sig til den praktiske praksis som en form for pædagogisk praksis, forstået som en formidlingspraksis uden at indfange den praktiske viden, som eksisterer inden for praktikfeltet i sin egen ret, og samtidig undlader at forholde sig til den teoretiske praksis, som også eksisterer i sin egen ret og som kunne bidrage til at afklare spørgsmål om praktikken.

\section{Pleje - som praktik og erkendelse i sin egen ret}

Kari Martinsens position er opmærksom på første del af denne problematik i sine filosofiske diskussioner af praktikerfaget sygeplejens nødvendige fastholdelse af praktikerens praktiske viden og erfaring og den deri virksomme praktiske erkendelse, som hun opfatter som en moralsk-faglig omsorgskompetence i praktisk tilstand (Martinsen, 1993).

Kari Martinsen er optaget af denne omsorgskompetence, praktikerens praktiske erkendelse, som i handlen fungerer som en ordløs praktik, og som skal bevæge sig mod en narrativ form, hvor omsorgskompetencens erfaringer kan ekspliciteres og diskuteres med andre kompetente praktikere samt videreformidles til nye i feltet (Martinsen, 1990b, s. 60-71). At sætte ord på sin praksis og samtale om praktikken er det, som giver fagligheden sin synlige eksplicitte form. Samtidig er det den faglighed, der primært skal formidles i uddannelsen af praktikere, som skal forstås som en mesterlære, hvor eleven lærer ved at deltage "i praktikken" og samtale "om praktikken". Hele denne erkendelsesproces foregår inden for en fænomenologisk-hermeneutisk diskurs. Den udøvende og den samtalende praktiker fungerer som fænomenologer for sig selv. 
Kari Martinsen fornægter ikke eksistensen af objektiverende natur- og socialvidenskab, som sygeplejefaget og den modsvarende uddannelse også omfatter. Men Kari Martinsens bidrag til diskussionen om den praktiske erkendelse er vedvarende at fremvise, at disse fagområder hverken teoretisk eller praktisk kan give det afsæt og den begrundelse som den praktiske sygepleje står på (Martinsen, 1990a). Natur- og socialvidenskaben kan fungere som en art hjælpediscipliner til indkredsning af de saglige forhold, sygeplejen også er underlagt og må forholde sig til, men den fænomenologisk-hermeneutiske orientering står i diametral modsætning til den objektiverende orientering. Kari Martinsen viser, at dette tydeliggøres gennem sproget, hvor den fænomenologiskhermeneutiske form har et narrativt fortællende sprog, mens den objektiverende natur- og socialvidenskab har et abstrakt-logisk sprog (Martinsen, 1990b, s. 71-76). Kari Martinsens position bevæger sig på mindst to niveauer.

- Dels gælder det for Kari Martinsen om, inden for feltet af en social interessekamp at modarbejde det sociale hierarki mellem den lægelige behandling og sygeplejerskernes pleje, men samtidig gælder det også om at modarbejde et nyt hierarki mellem den teoretiske og den praktiske sygepleje ved at fastholde og synliggøre eksistensen af plejen som praktik og som erkendelse i sin egen ret.

- Dels gælder det for Kari Martinsen om, inden for feltet af erkendelses- og videnskabsteoretiske positioner, at fastholde og synliggøre prioriteten omkring en fænomenologisk tilgang såvel $\mathrm{i}$ praktisk som i teoretisk tilstand frem for en objektiverende naturvidenskabelig tilgang. Den fænomenologiske tilgang er for Kari Martinsen fundamental ud fra sygeplejens væsen som en human-moralsk-faglig virksomhed.

\section{Refleksion over det intuitive}

Kari Martinsen tager i sin argumentation for læring i praktikken afsæt i Donald Schöns arbejder. Dels hans praktikepistemologi, dels hans uddybende diskussion omkring uddannelsestiltag (Schön, 1983, 1987).

Schöns praktikepistemologi bygger på store empiriske arbejder. Det er et deskriptivt studie af professionelle praktikere som arkitekter, psykoterapeuter, ingeniører, byplanlæggere og virksomhedsledere, og Schöns interesse er at få beskrevet, hvad det er for en type erkendelse, som den kompetente praktiker bruger i sin praksis, og hvordan denne viden adskiller sig fra den viden, som den professionelle praktiker har tilegnet sig gennem sine forberedende studier. Pointen for Schön er, at den kompetente praktiker ved mere, end han kan udtrykke, han har en "viden i praksis", hvoraf det meste er tavs. Samtidig viser det sig, at praktikeren udviser en evne til "refleksion i handlen' som baserer sig på refleksion over det intuitive; dvs. at det praktikeren umiddelbart føler er rigtigt i den givne situation, er det, som praktikeren handler på i de unikke og komplekse situationer, som praktikken er indlejret i.

Her adskiller Schön sig fra Dreyfusbrødrene, der ser ureflekteret intuition som udtryk for den virtuose kompetence. Schön arbejder med fire refleksionskategorier:

- $\quad$ "Viden i handlen", som er den intuitive spontane hverdagsviden, hvor vi bare gør tingene ureflekteret.

- $\quad$ "Refleksion i handlen", som er den reflekterede umiddelbare fornuft og meningsskaben gennem selvkritik enten i eller efter handlen. Det er at vide hvordan (knowing).

- "Refleksion i praksis" er den professionelle handlen, der implicerer de førnævnte kategorier. 
- $\quad$ "Rekonstrueret viden", som er forskerens rekonstruktion af den givne handlen. Det er at vide det (knowledge).

Det er Schöns intention at kunne karakterisere strukturen i den professionelle handlingsrefleksion. Schön har fat i nogle væsentlige aspekter af den praktiske erkendelse, men han overskrider ikke sin empirisk deskriptive tilgang, og man får derfor kun ansatser til det, som kunne blive et kvalificeret bidrag til en teori om den praktiske erkendelse. Man må forstå Schöns ansats som dele af et et opgør med den professionaliseringsekspansion som i USA har foranlediget, at også de fag vi i en dansk tradition kalder mellemuddannelser som f.eks. sygeplejerskeuddannelsen, for store områders vedkommende er dele af en universitær struktur, og hvor grupper, der efter endt uddannelse skal udøve konkret praktisk virksomhed, har gennemløbet universitetsstudier uden kontakt til den praksis de fremover skal være dele af og forventes at kunne håndtere. Dertil kommer at de fagområder, der læres gennem studierne, ikke umiddelbart synes at have relevans til den konkrete praksis. Schön forsøger med sit empiriske materiale at vise, at refleksion-i-handlen er lige så systematisk og stringent som den systematik, der kendetegner videnskabelig forskning og kontrollerede for $\varnothing \mathrm{g}$, og diskuterer følgelig grænserne for regelbundethed, som udtryk for myter om forholdet mellem tanke og handlen samt de interpersonelle og institutionelle sammenhænge, vi indgår $\mathrm{i}$.

Schön bliver næsten romantiker når han i sit arbejde mener, at det ville være muligt at slå bro over det gab, der eksisterer mellem praktik og teori, ved brug af hans egne overvejelser omkring praksisnære uddannelsestiltag.

\section{At anerkende den praktiske erkendelse i sin egen ret}

Patricia Benner repræsenterer i sit arbejde en position, der i nogen måde modsvarer Kari Martinsens. Benner tager primært afsæt i Dreyfusbrødrenes hierarkiske læringsmodel i sit empiriske studie af og forsvar for den kliniske sygeplejepraksis' virtuose kundskab imod den traditionelle sygeplejeforskning inden for sygeplejefeltet, der kopierer den medicinske klinik som anvendt objektiverende erfaringsvidenskab.

Benner afviser på den ene side en regelbaseret modeltænkning, men samtidig erstatter Benner denne tænkning med Dreyfus'ernes hierarkiske kompetencetrinsmodel, og understreger at hun ikke er for kaos og anarki i praktikken og gør sig til fortaler for en licensbaseret uddannelse. Benner laver en stipulativ beskrivelse af en ekspertpraksis og tesen er herefter, at man gennem videnskabelige studier og beskrivelse af ekspertviden kan formulere strategier for den kliniske sygeplejeviden således, at den kan udvikles og raffineres. Man sidder tilbage med spørgsmålet til hvad? Og for hvem?

- For at gøre den tavse viden til en eksplicit videnskabelig viden?

- For at gøre den tavse viden tilgængelig for praktikken med henblik på omorganisering heraf og undervisning heri?

I virkeligheden vil Benner begge dele, men man sidder igen tilbage med spørgsmålet: Hvorfor praktikeren skal gå omvejen om en videnskabelig beskrivelse af sin praktiske ekspertise for at formidle til andre, hvad eksperten ikke selv har været i stand til at tilegne sig gennem formidling. Teorien bliver selvgendrivende. Det forekommer i hvert fald ikke logisk hverken hos Kari Martinsen eller hos Benner, at den praktiske kunnen skal dokumenteres for at kunne videreformidles.

Benner, Dreyfus og Schön er fælles med Kari Martinsen i forsøget på at vise, at den drevne praktiker, den virtuose ekspertpraktiker, uanset om det drejer sig om en læge, en arkitekt, en terapeut, en manager og/eller en sygeplejerske, så bruger alle disse i deres praktik en praktisk 
erkendelse, som man ikke kan gøre rede for i en teoretisk diskurs, og som derfor heller ikke kan være anvendt videnskab. Det betyder:

- Eksperten handler ikke på den måde, at han konsulterer de indlærte teorier i sit hoved.

- Eksperten er ikke i stand til i objektiverende termer at verbalisere den viden, som han iværksætter i sin praksis.

Heraf følger, at det ikke umiddelbart er muligt at overføre ekspertviden i termer af et computerstyret program for eksempel, som Dreyfus'erne har vist det. Men også, at man ikke umiddelbart kan uddanne ikke-eksperter til at erhverve sig ekspertviden alene gennem teoretisk formidling, hvilket alt sammen er med til at forklare den professionskrise, der hersker inden for professionsuddannelserne selv, men kan også forklare myndigheder og klienters tillid eller mangel på samme til den videnskabsbaserede ekspertise, hvilket også er dele af Schöns ærinde.

\section{Hvad er videnskabens opgave over for praktikken?}

Schön, Benner og Martinsen, alle forfatterskaberne foranlediger spørgsmålet, som allerede Elzinga var inde på: Hvad skal man i det hele taget med videnskaben, når vi har med en praktikerdisciplin at gøre? Hvad er videnskabens opgave over for praktikken?

Man kan sige, at hele projektet med at videnskabeliggøre praktikken efterhånden heller ikke længere er troværdigt for praktikeren selv, som på en eller anden måde ved, at erkendelsesgrundlaget for praktikken er et andet end det, der udadtil legitimerer professionen, og hvor den professionelle legitimationskrise også i den folkelige opinion har skabt en mærkelig dobbelthed, der dels giver den sunde fornuft, folkelige visdom og professionelle erfaring hos den simple praktiker en st $\varnothing$ rre tillid end den anvendte videnskab, samtidig med at man har en ubegrænset tillid til alt det, som har med videnskab at gøre.

Inden for rammerne af den sociale interessekamp mellem positionerne i samfundet og inden for rammerne af den væsentligt større betydning, som formelle skolekundskaber er kommet til at spille i den kamp, har alle praktikererhverv fors $\varnothing$ gt at etablere sig som professioner baseret på formel uddannelse og i sidste ende baseret på formidling af videnskab. Det betyder efterhånden, at studier erstatter mesterlære, og teori erstatter praktik i uddannelser. Alt dette forårsager en radikal modsætning mellem ekspertpraktikerens anerkendelse af det virkelige erkendelsesgrundlag for hans/hendes ekspert-praktik og det grundlag og den uddannelse, som angiveligt legitimerer den praksis.

Det bliver derfor et centralt anliggende i diskussionen og definitionen af kompetence og i diskussionen og definitionen af uddannelse til den kompetence, at i hvert fald anerkendelsen af den praktiske erkendelse om ikke prioriteten er en størrelse i sin egen ret. Et forhold, som imidlertid ikke bliver enklere, når praktikeruddannelserne lægges ind i universitetsregi og får akademisk status uanset eller måske især ikke, hvis denne akademisering skulle være professionsrettet.

\section{Den objektiverede videnskabelige forklaring af praktikerens praktik er mulig}

Det er vanskeligt at bruge Bourdieu som inspirationskilde i denne diskussion, først af alt fordi Bourdieu ikke selv har beskæftiget sig med erkendelsesgrundlaget for professionelle praktikker. Bourdieu er primært optaget af at udarbejde en teori om de sociale hverdagspraktikker, som konstituerer et samfund, og om den modsvarende teoretiske praktik, som konstituerer samfundsvidenskaben. Når man alligevel tager Bourdieu som inspirationskilde, er det vigtigt at gøre sig klart, at man transformerer hans bidrag fra et domæne til et andet. At det er en vanskelig sag har 
allerede Benner vist; hun bruger bl.a. Bourdieu som belæg for, at teoretisk normalvidenskab af den naturvidenskabelige slags om praktisk handlen ikke er mulig, idet viden om praktisk handlen groft sagt bare kan være viden for praktisk handlen, det vil sige viden i første person singularis eller pluralis: den narrative fortælling eller samtale. Benner er her enig med Dreyfus'erne. Problemet er bare, at Bourdieu har brugt hele sit forfatterskab til at kritisere den tese, som Benner tager ham til indtægt for (Benner, 1984, p. 171 og Gordon, 1984, p. 228). Bourdieus social- og humanvidenskabelige praktikteori omfatter derimod følgende trin (Bourdieu, 1977, 1990 og Bourdieu, Chamboredon \& Passeron, 1991):

For det første den praktiske erkendelse, som praktikeren sætter i værk i og under selve handlingen. Den erkendelse er en praktisk sans, som bunder i en livslang erfaring med, hvad der rent faktisk kan lade sig gøre under givne omstændigheder. Det kritiske punkt i den opfattelse hos Bourdieu er, at den praktiske sans som følge af livslange tvungne erfaringer gør en dyd af nødvendigheden og derfor på enestående måde bliver adækvat med handlerummets objektive virkelighed. Det vil sige, at den praktiske sans er menneskelig, den kan vælge strategi inden for handlerummets grænser og er derfor ikke en ren refleks. Den er fornuftig, dvs. intentionel, men kun $f ø r$-bevidst, da den samtidig er bundet af sin erfaringshorisont.

For det andet den erkendelse, som ligger i praktikerens spontane oplevelse af sin praktik, hans/hendes hverdagsforestilling om, hvad praktikken går ud på. Den udtrykker ikke, hvad praktikken bliver, men det forhold, som praktikeren har til sin praktik, dvs. hvordan han har det med sin praktik. Derved bliver praktikerens oplevelse og de hverdagsord, som hverdagsbevidstheden i en given kultur sætter på praktikken ikke nødvendigvis adækvat med den praktik, som materialiserer sig objektivt set, og som tredje part kan stå og observere i en virtuel deltagende holdning.

Derfor kan oplevelsen, som praktikeren ser den, heller ikke alene være udgangspunktet for en adækvat forståelse af praktikkens totale indhold. Problemet med de fænomenologisk-hermeneutiske paradigmer er, at de ikke skelner mellem den iværksatte praktik og den primære oplevelse af praktikken, som praktikeren oplever den.

For Bourdieu er den første fase i et socialvidenskabeligt arbejde, som udføres i tredje person, at objektivere den observerede praktik og praktikerens primære oplevelse af den, for at rekonstruere, hvordan praktikken er indlejret i objektive betingelser, som praktikeren ikke selv har overblik over (Bourdieu et al., 1991).

Praktikeren kan ikke selv udtømmende gennemskue den praktik, som materialiseres, af den simple grund, at menneskelig handlen ikke kan forklares alene ud fra den handlendes bevidste intentioner og grunde. Den menneskelige praktik/handlen er også samtidig et stykke natur- og samfundshistorie, som sætter sig igennem bagom ryggen på alle bevidste intentioner. Den objektiverede videnskabelige forklaring er derfor mulig på trods af alt, hvad de foranstående paradigmer har forsøgt at gøre gældende. Den objektiverede videnskabelige forklaring, som må omfatte såvel indholdet i den objektivt materialiserede praktik, som indholdet i praktikerens mere eller mindre adækvate spontane oplevelse af den praktik, en spontan oplevelse, som er afhængiggjort af de objektive vilkår, som praktikken er indlejret i. 


\section{At lade praktikken fremtræde som praktiseret idé og som krop}

Bourdieu siger ikke dermed, at man kan afdække praktikerens erkendelsesgrundlag alene ved at gå til værks som de traditioner, som Martinsen, Benner, Dreyfus'erne, Schön m.fl. er op imod på grund af disse traditioners fejltolkning af, hvad naturvidenskaberne rent faktisk gør, nemlig at behandle menneskelig social praktik som ting. Det, der er vigtigt for Bourdieu, er at finde metodiske tilgange, som tillader forskeren at lade praktikken fremtræde ikke kun som en praktiseret idé, men også som krop (Bourdieu \& Wacquant, 1992), fordi praktikken er indlejret i en social verden og i naturen.

Endnu et forhold af praktikken bliver vigtig, når vi ser ikke alene på den implicitte kode, som har frembragt praktikken (den praktiske sans, sproget bag talen, drevenhed i skak bag spillet), men også ser på kodificeringer af praktikken, dvs. de lærde regelsystemer og forskrifter, som gør krav på at fortælle, hvordan man $b ø r$ gøre, men som i virkeligheden altid allerede er efterkonstruktioner og efterrationaliseringer af, hvad man plejer at gøre. Det er det, man inden for professionsuddannelserne almindeligvis benævner teori til forskel fra praktiske øvelser.

Praktikerens forhold til disse teorier eller kodificeringer kan udmønte sig forskelligt, men almindeligvis er praktikerens handlen ikke styret af disse kodificeringer, men af den praktiske sans, som kodificeringerne jo har efterrationaliseret. Selvfølgelig skal man kende reglerne for at kunne spille skak, men det er ikke det samme som at vide, hvordan man vinder, eller man skal kunne de elementære forskrifter for at være sygeplejerske, men det er ikke det samme som at man ved, hvordan man begår sig som sygeplejerske.

Men yderligere et forhold er vigtigt for Bourdieu, hvis man skal undgå den objektivistiske fejltagelse at tro, at de objektive regelmæssigheder, som forskeren ser i den observerede praktik, og som eventuelt er forskellig fra praktikerens primære forestillinger og idéer, og de kulturelle kodificeringer også skulle være det, som styrer praktikken. Det er vigtigt at medtænke, at praktikken nok fremtræder sådan for forskeren, men praktikken styres ikke af de observerede regelmæssigheder, på samme måde som praktikken ikke styres af de forskellige kulturelle kodificeringer, som er i miljøet. Også forskerens observerede regelmæssigheder er efterkonstruktioner.

Bourdieus pointe er, at praktikeren strategisk opfinder sin egen genvej til praktikken orienteret ud fra en praktisk sans, som han ikke selv kan gøre rede for og som kodificeringen og forskerens efterkonstruerede model ikke er dækkende for. Det betyder, at praktikken er genereret af en strategisk anvendelse af koden, den praktiske sans, af praktikeren selv i første person singularis, mens handlingen pågår og endnu ikke er fuldendt og derfor ikke kan fremstå som en model for hverken ham selv eller andre til efterfølgelse.

Med Bourdieu bliver praktikerens erkendelsesgrundlag problematiseret på flere niveauer, men først af alt viser Bourdieu, at det er muligt at konstruere en teori om de menneskelige praktikker, der er forklarende og i en vis forstand også forudsigende, i hvert fald situationsadækvat, samtidig med at hans teori problematiserer det herskende alternativ til den fænomenologiske tilgang til studiet af praktikerens erkendelse. 


\section{Litteratur}

Aristoteles (1936). Ethica Nicomachea. København: Levin og Munksgaard.

Benner, P. (1984). From Novice to Expert. Excellence and Power in Clinical Nursing Practice. Menlo Park, California: Addison-Wesley, Nursing Division.

Bourdieu, P. (1977). Outline of a Theory of Practice. Cambridge Studies in Social Anthropology.

Bourdieu, P. (1990). The Logic of Practice. Cambridge: Polity Press.

Bourdieu, P., Chamboredon, J-C. \& Passeron, J-C. (1991). The Craft of Sociology. Epistemological Preliminaries. Berlin, New York: Walter de Gruyter.

Bourdieu, P. \& Wacquant, L.J.D. (1992). An Invitation to Reflexive Sociology. Cambridge: Polity Press og Blackwell.

Callewaert, S. (1992). Kultur, pædagogik og videnskab. Om Pierre Bourdieus habitusbegreb og praktikteori. København: Akademisk Forlag.

Callewaert, S., Munk, M., Nørholm, M. \& Petersen, K.A. (Red.) (1994). Pierre Bourdieu. Centrale tekster inden for sociologi og kulturteori. København: Akademisk Forlag.

Carlgren, I. (1990). Den svårformulerade yrkeskunskapen. Nordisk Pedagogik, 10(3), 97-98.

Dreyfus, H.L. \& Dreyfus, S.E. (1986). Mind over Machine. The Power of Human Intuition and Expertise in the Era of the Computer. Oxford: Basil Blackwell.

Durkheim, É. (1972). Den sociologiske metode. Fremads videnskabelige serie, København: Fremad.

Durkheim, É. (1975). Opdragelse, uddannelse og sociologi. København: Carit Andersens Forlag og Finn Suensons Forlag.

Elbaz, F. (1983). Teacher thinking. A Study of Practical Knowledge. New York: Nichols Publishing Company.

Elzinga, A. (1989). Kunskapsanalys och klassanalys - med fokus på omvårdnadsforskning. I S. Selander. (Red.), Kampen om yrkesutøvning, status och kunskap. (s. 125-145). Lund: Studentlitteratur.

Elzinga, A. (1990). Vem talar om tyst kunskap-och varför? I. Nordisk pedagogik, 90(3).

Erslev Andersen, J., Schanz, H-J. \& Stounbjerg, P. (Red.) (1983). Det Moderne - en bog om Jürgen Habermas. Århus: Modtryk.

Foucault, M. (1973). The Birth of the Clinic. An Archaeology of Medical Perception. USA: Vintage Books.

Foucault, M. (1977). Overvågning og straf. København: Rhodos.

Gordon, D.R. (1984). Research Applications: Identifying the Use and Misuse of Formal Models in Nursing Practice. I P. Benner (Red.), From Novice to Expert. Excellence and Power in Clinical Nursing Practice (s. 225-243). Menlo Park, California: Addison-Wesley.

Göranzon, B. (1990). Det praktiska intellektet. Stockholm: Carlssons.

Hansen, K.G. (1988). Intuitionens rationalitet og indlevelsens objektivitet. Om kvindeforskningens bidrag til forståelse af den videnskabelige erkendelse. Paradigma, nr. 2.

Heyman, Ingrid (1995). Sjuksköterskors avhandlingar under åren 1974 till 1991. En analys av omvårdnadsforskningens framväkst i Sverige. Pro manuscripto underlag för seminarium, mars 1995. HLS, Stockholm: Duvslaget.

Josefson, I. (1991). Kunskapens former. Det reflekterade yrkeskunnandet. Stockholm: Carlssons. 
Jørgensen, A.M. (1993). En diskussion af: Hvilken betydning har teori for praktik? Hvad er erkendelsesgrundlagetfor praktik? Her relateret til et konkret empirisk observationsstudium. (Kandidatspeciale). Institut for Filosofi, Pædagogik og Retorik. Københavns Universitet.

Jørgensen, E.B. (1993). Myten om ‘fysiske’, ‘psykiske`og `sociale` sygeplejepraktikker. Philosophia, 22, Århus, s. 83-96.

Jørgensen, E.B. (Red.) (1994). En antologi om sundheds-og sygepleje. København: Akademisk Forlag.

Kuhn, T.S. (1973). Videnskabens revolutioner. København: Fremad.

Larsen, K. (1991). Klinisk Sygeplejepraksis. En diskussion af praktisk viden og kunnen relateret til et konkret observationsstudie. Her inddrages Pierre Bourdieu's praktikteori og Donald Schön's erkendelsesteori. Opgave i emneområde 2. Institut for Pædagogik, Københavns Universitet.

Larsen, K. (1994). Teori og praksis i sygeplejerskeuddannelsen. En empirisk unders $\varnothing$ gelse af forholdet mellem teori og praksis i sygeplejerskeuddannelsen. (Kandidatspeciale). Skriftserie, nr. 16, Danmarks Sygeplejerskehøjskole, Aarhus Universitet.

Lindgren, G. (1992). Doktorer, systrar och flickor. Om informell makt. Stockholm: Carlssons.

Martinsen, K. (1990a). - Jeg vil bruke min teoretiske viten til å fremme respekten for praksis og praksis-kunnskap. Intervju. Milepælen. Tidskrift for Høgskoleutdanning i Helse- og Sosialfag, nr. 1, peg. 1., s. 7-10, 21-23.

Martinsen, K. (1990b). Moralsk praksis og dokumentasjon i praktisk sykepleie. I T. K. Jensen, L. A. Jensen \& W. C. Kim (Red.), Grundlagsproblemer i sygepleien. Etik i videnskabsteori, ledelse og samfund (s. 60-84). Århus: Philosophia.

Martinsen, K. (1993). Fra Marx til Løgstrup. Om etikk og sanselighet i sykepleien. Norge: Tano.

Petersen, K.A. (1989/90). Habitusbegrebet hos Bourdieu - teoretiske overvejelser og indledende metodediskussion til empirisk indkredsning af sygeplejehabitus. Eksamensopgave. Institut for Pædagogik, Københavns Universitet, upubl.

Petersen, K.A. (1992). "Der ønskes en redegørelse for nyere teorier om praktikernes erkendelsesgrundlag". Magisterforelæsning. Institut for Filosofi, Pædagogik og Retorik, Københavns Universitet, upubl.

Petersen, K.A. (1993). Den praktiske erkendelse. Forholdet mellem teori og praksis i sygeplejen og sygeplejerskeuddannelsen. Konferensspeciale. Skriftserie, nr. 4, Danmarks Sygeplejerskehøjskole, Århus: Aarhus Universitet.

Petersen, K.A. (Red.)(1995a). Praktikteori i sundhedsvidenskab. København: Akademisk Forlag.

Petersen, K.A. (1995b). Kunst, praksisteori og videnskab. FS 13 nyt, nr. 1, Faglig Sammenslutning for Sygeplejersker beskæftiget med onkologi, s. 34-45.

Polanyi, M. (1967). The Tacit Dimension. New York: Doubleday.

Schön, D. (1983). The Reflective Practitioner, How Professionals Think in Action. New York: Basic Books.

Schön, D. (1987). Educating the Reflective practitioner. San Francisco, London: Jossey-Brass. 